\title{
Private Property Rights, Government Interventionism and Welfare Economics
}

\section{Ivan Jankovic, ${ }^{1}$ Walter Block ${ }^{2}$}

\begin{abstract}
We develop a critique of government interventionism based on the Misesian calculation argument against socialism. If private property rights and relative prices based on supply and demand are necessary for successful economic coordination, then conventional market failure theories cannot be sustained. Government interventionism based on the idea of correcting "market failures" is analytically just a milder form of socialist central planning. Between the two, there are only differences in degree, not in kind. We criticize several public choice and law and economics scholars for disregarding this Misesian angle in their market failure theories. In our view they are reducible to arguments based on a fallacious political economy while perpetuating false neoclassical economic analysis of market failure theorists. We claim that government interventionism is just a milder form of socialist central planning. Therefore, the traditional arguments against the efficiency of central planning also apply to government interventions aiming at fixing market failures. In particular, we maintain that governments face the "knowledge problem", which means that they cannot determine the optimal allocation of resources. In section two of this paper we discuss market failure and economic calculation. Section three is given over to our claim that the "Nirvana fallacy" is itself fallacious. The burden of section four is to address Coase and consequences. We conclude in section five.
\end{abstract}

Keywords: Government failure; market failure; prices; private property rights; subjectivism; socialism; public choice

JEL Classification: A13

Received: 7 June 2019 / Accepted: 15 November 2019/Sent for Publication: 5 December 2019

\section{Introduction}

Ludwig von Mises and F.A. Hayek developed a far-reaching critique of the possibility of rational economic planning under socialism. According to their arguments, without

\footnotetext{
${ }^{1}$ Assistant Professor of Economics, University of Mary, Bismarck, ND, USA. The author could be reached atijankovic@umary.edu.

${ }^{2}$ Harold E. Wirth Eminent Scholar Endowed Chair and Professor of Economics at Loyola University New Orleans, USA. The corresponding author, he may be reached at wblock@loyno.edu.
}

(C) 2019 by the authors; licensee Review of Economic Perspectives / Národohospodářský obzor, Masaryk University, Faculty of Economics and Administration, Brno, Czech Republic. This article is an open access article distributed under the terms and conditions of the Creative Commons Attribution 3.0 license, Attribution - Non Commercial - No Derivatives. 
private property rights in the means of production, supply and demand and market prices of the factors of production could not be established, and knowledge about relative scarcity of different goods becomes impossible to discover. This leads to a situation where the distinction between good and bad economic decisions disappears, and the waste of resources becomes a norm.

This argument for the impossibility of socialist central planning is widely accepted among Austrian economists. Yet, some of its radical consequences are not well understood or appreciated. One of the peskiest aspects of the theory, that the present paper will try to spell out, is that it establishes ex-ante economic inefficiency of any government action to improve social welfare in the market economy, and not only under socialism. If the Mises-Hayek ${ }^{3}$ thesis proves socialist central planning cannot work, it also demonstrates that, ipso facto, government interventions to correct the externalities, provide "public goods" and correct information asymmetry is a will 'o the wisp. One can support either the Mises-Hayek critique of socialism or any kind of market failure theory, but not both. This is the central claim of the present paper.

In this connection, the so-called government failure critiques of standard economic arguments for intervention, developed by the public choice and law and economics traditions, are equally unsound. Both paradigms assume that the costs of government intervention can be established and measured ex-ante by some nonmarket agent (be it the government, central planner, judge, etc.); that relative prices could be determined without strict private property rights; and that, at least theoretically, government action can increase social welfare and be Pareto optimal (or at least Kaldor-Hicks efficient). This is as false as the claim that a central planner can know the opportunity costs of resources absent market prices.

\section{Market failure and economic calculation}

The first step in demonstrating this thesis is to contrast the so-called market failure teachings with Mises's $(1922,1990)$ argument against the possibility of economic calculation under socialism. The reason for doing so is to emphasize that the concept of market failure is based on the same assumptions Mises criticized in socialism, pertaining to the role of market prices in economic calculation. The market failure theorists, we argue, display the same lack of understanding of the function of market prices that Mises diagnosed in his critique of the supporters of socialism. It is against this background of understanding the function of prices that the theoretical differences between the two approaches can best be seen. Then we shall compare the conclusions of both with government failure theory and establish that they fall into the same category as the market

\footnotetext{
${ }^{3}$ There is a large, important, de-homogenization literature demonstrating that there are large differences between these two scholars; we support it, but, abstract from it in the present paper. See on this Block and Garschina (1996); Ebeling (1992); Herbener (1991); Hoppe (1996); Knott, (2012); Rothbard (1991, 1992); Salerno (1990a, 1990b, 1991, 1992, 1993, 1995); Stalebrink,(2004); for a critique, see Kirzner (1996).
} 
failure doctrines, and radically break with the Misesian paradigm (shared by many other authors, such as Hayek and Buchanan).

Mises emphasizes a positive function for market prices in his theory of economic calculation; he argues that socialist calculation is impossible because in it the price system would not function, which is the only rational way of coordinating the economic activities in a large, industrial society (Mises, 1990). This author employs a simple and elegant logical sequence which demonstrates the impossibility of rational planning of economic activity under socialism; this system involves abolishing private property in the means of production; eradicating private property means elimination of the forces of supply and demand; this, in turn, implies that no sensible market prices for goods and services, and especially for production factors, can be established anymore. This further entails that profit and loss disappear entirely, and cost-accounting also becomes impossible. The result is that the relative scarcity of productive factors remains unknown, and hence the difference between a good and bad investment decision is impossible to define, let alone accomplish. Socialism in economic sense becomes a "leap in the dark" (Mises, 1951: 122), a tremendous waste of economic resources.

It is very important to note that Mises understands money prices as the only medium through which it is possible to perform the calculation with cardinal numbers. In the absence of genuine market prices, based on the private ownership in the means of production, not only does conventional business cost-accounting become impossible but this also applies to any discussion about the "cost of government intervention" - the relative utility gains and losses that different individuals could derive from alternative government interventions. Cost is an economic category that is subjective, and no outside observer, analyst or economist can know, apart from an entrepreneurial act of choosing, what the "real" economic cost of any action was (Mises, 1949, Buchanan, 1969). ${ }^{4}$ In Mises' world an entrepreneur faced with market prices and praxeological uncertainty is the only agent capable of making any kind of ex-ante "cost-benefit" analysis; a government bureaucrat, a judge or a socialist central planner are equally incapable of determining the real opportunity cost of any market operation or governmental action. The costs, benefits, and utility attain their full meaning only in the context of private markets with genuine monetary prices. ${ }^{5}$

\footnotetext{
${ }^{4}$ It is the rare mainstream micro-economics textbook that does not define costs correctly in this subjective manner: as alternatives or opportunities foregone. However, when we next meet this concept, in a later chapter, it is via the intermediation of "cost curves." But these are objective. How the twain ever meet is never explained. Not only can others not know of our costs, apart from action, we do not know them either. Those perusing this paper are doing so at the cost of foregoing other options. What are they? Who knows? Perhaps swimming, eating, reading something else, sleeping, etc. Yet, how many readers were ever aware of this, other than when we now mention it. Very few. A further discussion of this issue appears in section 3.

${ }^{5}$ As Herbener correctly points out, the context of monetary, private property economy is the only context in which the social wealth can be sensibly defined: "...entrepreneurial calculations of profit allow for cardinal comparisons of the social value of consumer goods produced...with the social value of factors used. Whenever an entrepreneur earns profit, social wealth increases; anytime he suffers a loss, the social wealth decreases" (Herbener, 1997: 81-82).
} 
Unlike Mises, the market failure theorists turn their attention to those cases where genuine monetary prices appear not to exist or not to function "properly": instances in which in their opinion the market mechanism fails to price certain resources or activities "efficiently". According to them, this in itself calls for government action to rectify these economic inefficiencies. The entire theory is based on the (almost always implicit) assumption that the state can know the "true costs" of human action, independently of monetary exchange and market evaluation. So, in one important sense, all market failure theories are "price failure" theories.

One of the most common of these "price failure" theories pertains to the so-called problem of "public goods"; according to the theory, there are some "inclusive" goods, whose use cannot be properly priced because it's impossible to exclude anyone from using them, for example national defense and lighthouses. Hence, no one has an incentive to pay for the provision of those goods; nor is there any legal way of preventing or subsequently punishing free riders. Thus, it is only possible for society to have any of those goods at all is to set up a government monopoly, financed by forced transfers of money - taxation (Samuelson, 1954). Another difficulty with public goods, according to those who claim it is an instance of market failure, is lack of rivalrousness. Even if we could exclude non-payers, economic efficiency mandates that we do no such thing, since allowing them to utilize the product costs no one anything. For example, according to this pernicious doctrine, once a radio or television broadcast is set up, the marginal costs of adding one more person to the subscriber list is effectively zero. Viewers are not "rivals" with one another for the use of this service, as they are for more pedestrian goods and services such as clothing or food or automobiles or pencils. Thus, even if we could preclude a non-payer from enjoying the show, we should not do so. ${ }^{6}$

However, here is the rub: if Mises is correct in saying that the critical reason why socialism represents an economic "leap in the dark" is the absence of private property in the means of production, how exactly is public goods production any different? Public goods exist precisely because private property rights in them do not exist (for whatever reason). Private property rights are either a precondition of rational economic planning or they are not. We cannot have it both ways. Upon pain of self-contradiction, we cannot renounce socialism and then in the same breath support the doctrine of public goods. If we do so, we espouse a theory of socialism (abolishing private property) as both the cause of the disintegration of the economic system and its salvation from market failures. $^{7}$

\footnotetext{
${ }^{6}$ In the text we sketch out an extreme interpretation of this doctrine. A more moderate rendition would claim not that no non-payers can be excluded from the benefits, but that many cannot; not that we will have no lighthouses or national defense, but too few or too little of them.

${ }^{7}$ Sometimes a question is asked: how does the private firm operation compare to the activities of the government? According to the canonical Coasean (Coase, 1988; Coase, 1937) theory, every firm is an island of central planning within a large sea of market price competition. By the same token, a single government agency is also an island. If we accept the efficiency of private firms what is different with government agencies correcting market failures? There are two reasons we reject this comparison. First, we think that an alternative, non-central planning theory of the firm
} 
Another form of "market failure" is so-called "externalities"; according to this theory the price system yet again errs because some economic activity, e.g. pollution, inflicts costs onto third parties which are not "internalized" e.g., paid for by those who produce them. Private accounting costs of a polluting firm tend to be much lower than the real "social cost" they inflict on society by damaging other people's property and health. The market fails to properly price these effects of pollution. Hence, it is argued, a compensatory action by the government is needed in the form of penalties for the polluters and/or subsidies for the victims to make the private costs approximate the objective social cost of pollution (Pigou, 1932). So much for negative externalities or external diseconomies. There are also positive externalities or external economies. Here, man A benefits man B, and yet the former cannot charge the latter for this assistance. For example, education. Some of its benefits are indeed captured by the educated person in the form of higher salaries, better contacts, etc. No externality there. But other aspects of it "spillover" to third parties. For example, those who partake of schooling especially at the advanced level supposedly become more informed voters, less given to crime, than otherwise would be the case. All the rest of us gain from these expenditures on teachers and books, and yet we cannot be compelled to pay for this service. Enter the favorite institution of the statists, who force us to do just that, via compulsory taxes, a redundancy (Friedman, 1962, pp. 85-107).

The problem with this concerns the same vexatious private property rights and how they affect the reasoning about market efficiency. As Harold Demsetz (1969: 348) demonstrated, externalities represent an epiphenomenon of the absence of private property rights: "A primary function of property rights is that of guiding incentives to achieve a greater internalization of externalities. Every cost and benefit associated with social interdependencies is a potential externality." If this is so, then the existence of externalities in the sense of the price theoretical analysis is no different than the presence of socialism in Mises' sense. Both describe what happens when there are no private property rights in scarce goods; it results in a breakdown of economic calculation and the same "leap in the dark". Hence, the idea that the government can help with the "internalization of externalities" by taxes or subsidies is no more sensible than the suggestion that the state can solve the problem of the shortage of steel or milk under Communism. The same economists who solemnly declare their unwavering opposition to price controls as a form of socialism in effect embrace them to "solve" the problem of externalities in capitalism. The price of carbon dioxide is not "correct" because there are no private property rights in environmental goods, but don't worry, we are going to figure out what the "true", "economically efficient" price of carbon dioxide should be, even without property rights.

Yet another iteration of so-called market failure theories is the doctrine of "information asymmetry". This theory asserts that real markets often fail, or are "incomplete", be-

(Alchain and Demsetz, 1972; Jensen and Meckling 1976, Fama 1980, Jankovic, 2010, 2015) emphasizing the nature of the firm as a voluntary network of contracts and markets, is more convincing than the Coasean theory. And second, even if we disregard this, the Coasean firm is subject to the profit and loss test. It knows when it made a mistake and when it made a good decision. The government is not a subject to the same test and consequently does not know and cannot know whether it made a good or a bad decision. 
cause information is not equally distributed, i.e., there is an information "asymmetry" among the various market actors. This violates one of the basic assumptions of perfectly competitive equilibrium; namely that information is free, perfect and equally available to all market participants (Stiglitz and Weiss, 1981, Akerlof, 1970). ${ }^{8}$

In one of the canonical modern expositions of the externality problem in the context of asymmetric information and "incomplete markets", it is argued that private firms and households leave potential gains on the table after their transactions are done, that government can discover and realize them, making everyone better off in the process (Stiglitz and Greenwald, 1986). According to these authors: "There exist government interventions (e.g., taxes and subsidies) that can make everyone better off" (Greenwald and Stiglitz, ibid.). This is a simple rendition of the Pareto rule, that an intervention is Pareto improving when it increases the welfare of at least one member of society, while no one else's welfare is decreased.

Greenwald and Stiglitz (1986) analyze how government intervention could Paretooptimize the choices of firms and households through various policies of taxation and redistribution. In their model, firms maximize profit, households maximize utility. The latter is modeled via two separate elements; prices and externalities. Households buy and sell goods and have budget constraints, based on which they optimize. However, externalities affect utility but do not have a monetary value and hence do not appear in budget calculations as costs. This leaves the households worse off than they would otherwise be, but for this "failure". The same applies to firms. The function of government is to optimize their situations by giving subsidies to companies and lump-sum transfers to households to make up for the utility loss stemming from these externalities.

Let us consider one simple example. Discussing how taxes on consuming alcohol should be set in order to undo the externality in the form of increased car accidents, these authors write: "The tax should be increased until the marginal deadweight loss (the constant rate loss in tax revenue) exactly balances the marginal benefits of reductions in the accident costs that have not been internalized by the individual (the accident externalities)" (Greenwald and Stiglitz, 1986: 238). So the tax rate should equalize marginal costs and marginal benefits of taxation. The major problems with this ${ }^{9}$ are how to determine the objective "marginal costs" and "marginal benefits" of anything without a market pricing system? And why would the government be any better in figuring out those costs and benefits than the private actors?

These authors never explain how this is possible. They assume that if a market "failed," then the government must be the solution. This is one of the most salient features of all market failure theories; a peculiar faith in a kind of hidden, predetermined harmony

\footnotetext{
${ }^{8}$ For a critical account see Cowen and Crampton (2002); Anderson (2001); DiLorenzo (2011); MacKenzie,(2003).

${ }^{9}$ This is from their own point of view. From our perspective, there is also the fallacy of interpersonal comparisons of utility; these authors rely on this, yet it is entirely invalid. Another difficulty is that they see utility in terms of cardinality; it can be measured. In the Austrian tradition, in sharp contrast, there is no such thing as "utils" or units of happiness. There is only ordinal utility. A person prefers X to Y. See on this Rothbard (1956).
} 
among markets and government. Whenever the market is considered "efficient", government intervention is deemed unnecessary and even harmful; ${ }^{10}$ whenever market "fails" (and that is, very often), the very same government that had been deemed incapable of mimicking the market in far less problematic cases becomes miraculously the preferred solution to those new, much graver, problems. This is obvious when we observe how Stiglitz describes Hayek's argument against perfect competition: "The new information economics substantiates Hayek's contention that central planning faces problems because it requires an impossible agglomeration of information. It agrees with Hayek that the virtue of markets is that they make use of the dispersed information held by different participants in the market. But information economics does not agree with Hayek's assertion that markets act efficiently" (Stiglitz, 2008).

It is obvious that Stiglitz fundamentally misunderstands Hayek. ${ }^{11}$ The very notion of "efficiency" that Stiglitz uses does not make any sense within the Hayekian setting: what Stiglitz means by this notion is the technical optimality of transforming a given knowledge into production outcomes; in sharp contrast, what Hayek means by "efficiency" is discovering the knowledge that we do not have ex-ante. If economically relevant information ${ }^{12}$ is indeed dispersed and decentralized, and if the market is understood as a mechanism for collecting and utilizing this otherwise inaccessible information - then it is completely nonsensical to insist on having ex-ante knowledge as a precondition of market efficiency. The market exists exactly because we do not have exante knowledge about the best way to combine resources. There is not in Hayek's view any additional 'efficiency' that the market is required to have beyond its role in agglomerating and utilizing dispersed knowledge:

"The peculiar character of the problem of a rational economic order is determined precisely by the fact that the knowledge of the circumstances of which we must make use never exists in concentrated or integrated form but solely as the dispersed bits of incomplete and frequently contradictory knowledge which all the separate individuals possess. The economic problem of society is thus not merely a problem of how to allocate 'given' resources - if 'given' is taken to mean given to a single mind which deliberately solves the problem set by these 'data.' It is rather a problem of how to secure the best use of resources known to any of the members of society, for ends whose relative importance only these individuals know. Or, to put it briefly, it is a problem of the utilization of knowledge which is not given to anyone in its totality." (Hayek, 1936: 521)

\footnotetext{
${ }^{10}$ This occurs for mainstream neo-classical economists only under the stringent assumptions of "perfect competition." Here, there are an indefinitely large number of homogeneous firms, there is perfect information on the part of all market participants, profits are zero, firm size is insignificant, there is no entrepreneurship, we are always at equilibrium, etc.; this is only the tip of the ice-berg of unrealistic assumptions. For criticisms of this model, see Hayek (1964, 2010); Lewin and Phelan (1999); Machovec (1995); Reisman (2005); Rothbard (1961); Salerno (2011); Salin (1996); Schrepel (2015).

${ }^{11}$ According to the latter: Hayek (1964, p. 96) "In perfect competition there is no competition..."

${ }^{12}$ For more on the information problem, see Caldwell (1997); Sobel and Leeson (2006); Williamson (2010); Zhangkai, et al. (2017).
} 
The fact that this form of efficiency does not fit the concept of optimization of neoclassical models, is for Hayek a very good argument against those models. On the contrary, for Stiglitz the fact that economic actors in real markets do not have free information ex-ante, as in the model, is not an argument against the model, or at least against using it as a benchmark for public policy, but against markets, i.e. reality! For Stiglitz, markets without perfect information are "inefficient". That is exactly why we need government intervention - to make them "efficient"! This does not mean that Stiglitz doctrinally supports full-blown socialism. Au contraire he accepts Hayek's critique of socialism, the notion that socialist government cannot "agglomerate" all necessary information to coordinate economic activities. Stiglitz only rejects the idea that the same argument applies to interventionist governments in capitalist or social-democratic societies!

However, this is a problem. It is not clear why the same government agents have superior epistemological and entrepreneurial abilities only in the cases of public goods, externalities or information asymmetry, and other such "market failures," but not regarding normal production that conforms to the perfect competition model - say, ordinary industrial manufacturing. Hayek is either right or wrong when he says that the government cannot agglomerate dispersed knowledge; he cannot possibly be both correct in the case of socialism and incorrect in the case of interventionism. Where is the relevant difference between the two? If extra-market agents can provide superior, Pareto optimal solutions to the problems the market fails to address, one would logically expect them to be even more successful in resolving "normal"' economic challenges, which a market itself can properly address in most cases, even according to its most bitter critics, the very same advocates of "market failure." Why should government be limited to correcting externalities and providing public goods and not be allowed to own and operate food chains, automobile plants or agricultural lands? If taxes, subsidies, and regulations could correct "imperfections" of the market, why then outright central planning should not be fully capable of attaining "perfection" in the more ordinary operation of the market? Why would we allow a wasteful and time-consuming process of competition to operate, to achieve the same solution that the government bureaucrat can achieve instantly, ex definitionem ${ }^{13}$

${ }^{13}$ Here is the locus classicus from Hayek (2002: 9) asking a similar question: "It would not be easy to defend macroeconomists against the charge that for 40 or 50 years they have investigated competition primarily under assumptions which, if they were actually true, would make competition completely useless and uninteresting. If anyone actually knew everything that economic theory designated as data, competition would indeed be a highly wasteful method of securing adjustment to these facts." A very helpful referee of this journal suggests that in a previous version of this paper, we overlook the so-called market failures of asymmetric information and public goods. It would take us too far afield to explain why we reject these claims of market failure. We content ourselves with mentioning several refutations of this doctrine. On public goods Rothbard's $(1997,178)$ reductio absurdum is as follows: " $\mathrm{A}$ and B often benefit, it is held, if they can force $\mathrm{C}$ into doing something. . . . [A]ny argument proclaiming the right and goodness of, say, three neighbors, who yearn to form a string quartet, forcing a fourth neighbor at bayonet point to learn and play the viola, is hardly deserving of sober comment." For more in this vein see Barnett and Block (2007, 2009); Block ( 1983, 2003b); Block and Nelson (2015); Cowen (1988); De Jasay (1989); Holcombe (1997); Hoppe (1989); Hummel (1990); Osterfeld (1989); Nelson and 
A simple conclusion from the foregoing would be that if Pareto optimal government intervention is theoretically possible, then this applies as well to central planning. The market failure theorists agree with Mises that when the market fails that is because there are no private property rights that would create supply and demand ${ }^{14}$ and hence a lack of the prices which would allow the economizing of scarce resources. Where they part ways is that in the Misesian perspective, it is not immediately obvious how governments could make up for this deficiency, i.e. create a surrogate of economic calculation in the absence of genuine money prices, to mimic what the "perfect" market would have done. On the other hand, market failure theorists assume that precisely this is indeed possible. Hence, one cannot accept both the Mises Impossibility theorem and Stiglitz's Pareto optimal intervention at the same time. It has to be one or the other. ${ }^{15}$

Let us now try to show that the "government failure" theorists accept Stiglitz's rather than Mises' theorem, and they do so at their intellectual peril.

\section{The fallacy of "Nirvana fallacy"}

The main discovery of the public choice literature 16 was that apart from market failures and costs, there are often neglected, but real, the costs of using government. The state is not well-greased welfare-maximizing machine, but rather a messy process of transforming individual preferences into presumably efficient pubic policies, a process that itself often fails. One of the chief theoretical innovations that allowed Public Choice to emerge as a distinct and influential school of thought was its rejection of the "public interest" rationale for government action, a belief in the benign, angelic, and selfless bureaucrat-public servant. Instead, they treated politics as just one more market, among others, where political agents pursue their own personal goals, instead of maximizing social welfare or utility (Buchanan and Tullock, 1962; Tollison and McKormick, 1981). For them, there is no difference between homo economicus and homo politicus. The proponents of public choice returned to the old, classical liberal skepticism toward politics, and reject what Robert Tollison called a "Doctor Jekyll and Mister Hyde" political anthropology (Tollison and McKormick, 1981).

The public choice literature offers a wide array of explanations as to why politics is a market, and why and how that political market "fails". Included are the so-called ration-

Block (2018); Pasour (1981); Rothbard (1985, 1997c); Schmidtz (1991); Sechrest (2003, 2004a, 2004b, 2007); Tinsley (1999) . On asymmetric information, see: Anderson ( 2001, 2018); DiLorenzo (2011); Ebeling (2017); Fox (2017); MacKenzie (2003); Sutter (1995); Westley (2012); Woods (2009a, 2009b, 2009c)

${ }^{14} \mathrm{And} /$ or they are greatly attenuated.

${ }^{15}$ It is interesting that Mises himself treats the problem of externality in Mises (1949: 650-656). However, he does not relate it in any way with economic calculation, nor does he objects to Pigou explicitly (although he identifies the problem as the absence of private property rights in goods in services whose production inflicts external costs, (see, ibid.)).

${ }^{16}$ For a general critique of the school of Public Choice, although not on the ground mentioned in the text, see Block (2000b; 2005); Block and DiLorenzo (2000, 2001); DiLorenzo (1984, 1987, 1988, 1990, 2002); DiLorenzo and Block (2001, 2016); Higgs (2016); Mackenzie, Unpublished; Pasour (1986); Rothbard (1997b, 2011); Stringham (2005). 
al ignorance of the voters (Caplan, 2007), rent-seeking, 17 logrolling, corruption, 18 bureaucracy 19, and many other anomalies of the political process that prevent it from becoming "perfectly competitive", i.e. obstruct a smooth transformation of the individual preferences of voters into the "optimal" public policies.20 For example, bureaucracy has a goal-function within the public choice model to "maximize its budget" (Niskanen, 1971). This means that a bureaucrat would tend to expand his activities and to ask for more funds and regulatory powers, irrespective of the results of his previous actions. The objective of the bureaucrat is therefore not to solve problems, but to create and exacerbate them, to justify the existence of his bureaus in the first place, and to increase its prestige and funding. With such a structure of incentives embedded into the functioning of government it is not surprising that the results of intervention are often disappointing. ${ }^{21}$

Notice that public choice theorists assume that private markets are efficient in terms of the conventional neoclassical model; they just do not think that the same applies to the political markets as well. As prominent members of this school McChesney and Shugart (1995: 7-8), observe: "Homo politicus and homo economics are the same. The critical implication of this assumption of universal self-interest is that the observed differences between public choices and private choices not because individuals adopt different behavioral objectives in the two settings, but rather because the constraints on behavior are different." The "constraints on behavior" that bring about such different outcomes in the political arena, as opposed to the economic one, are exactly those deformations of the political system that prevent it from mirroring the superior efficiency of the private markets in accommodating their standards. ${ }^{22}$

Therefore, the theoretical reach of the public choice critique of government interventionism is rather limited; a social optimum could still be theoretically achieved by political means, and the only reason why this usually does not happen in practice, has to do with the incentives structure within the state itself. Since political actors, and not only the market entrepreneurs, act in their self-interest rather than in the public interest, and political "constraints" on individual behavior are loose, socially "suboptimal" outcomes may emerge. The problem with government failure is not that political actors do not have the cognitive and epistemological capabilities to correct market inefficiencies but that the imperfect political markets create moral hazard allowing them to avoid the blame for their failures. They do not bear the full cost of their actions: "...in private markets self-interested voters and politicians make choices that mainly affect themselves, while in political markets self-interested voters and politicians make choices that mainly affect others" (McChesney and Shugart, ibid.).

\footnotetext{
${ }^{17}$ For a critique of this verbiage, but not the concept, see Bhagwati (1982); Block (2000a, 2002, 2015); Henderson ( 2008); MacCallum (2015); Pasour (1986); Wenzel (2016a, 2016b).

${ }^{18}$ For a defense of this practice, see Block (1976), "The dishonest cop"

${ }^{19}$ For an Austrian School treatment of this phenomenon, see Mises (1969).

${ }^{20}$ See Buchanan and Tullock (1962).

${ }^{21}$ To everyone else, that is, but the bureaucrat and his corporate capitalist cronies.

${ }^{22}$ This is the reason why James Buchanan said that "there is no a political analogue to the invisible hand".
} 
Hence, the problem is not that the information about social optimum is unavailable to the political actor ex definitionem, but only that his ability to socialize the costs of his decisions makes this information practically unusable The inefficiencies of the political decision-making process preclude utilizing the (available) information concerning the social optimum from crystallizing into the concrete, optimizing actions and policies. There is no doubt, however, that the information itself exists "out there". The public choice school accepts that Pareto Optimal government intervention is possible; it only adds a minor pragmatic reservation that such an outcome is often not likely.

This can best be seen if we analyze the famous "Nirvana Fallacy" theorem of Harold Demsetz (1969: 1) which has become an often-cited conceptualization of government failure theory:

"The view that now pervades much public policy economics implicitly presents the relevant choice as between an ideal norm and an existing 'imperfect' institutional arrangement. This nirvana approach differs considerably from a comparative institution approach in which the relevant choice is between alternative real institutional arrangements. In practice, those who adopt the nirvana viewpoint seek to discover discrepancies between the ideal and the real, and if discrepancies are found, they deduce that the real is inefficient. Users of the comparative institution approach attempt to assess which alternative real institutional arrangement seems best able to cope with the economic problem; practitioners of this approach may use an ideal norm to provide standards from which divergences are assessed for all practical alternatives of interest and select as efficient that alternative which seems most likely to minimize the divergence."

As we easily can see from this famous quotation, Demsetz deviates theoretically very little from the standard market failure models. The only significant difference is his discovery that something is wrong with the old view that there always has to be a "predetermined" harmony between markets and government: namely, that finding some "imperfections" in the market (namely, some departures from the neoclassical models) is a sufficient condition to require and justify government correction of this "imperfection". Demsetz warns that this reasoning is too simplistic; state intervention could make things even worse (exactly for the reasons discussed in the previous paragraphs!). Thus before one engages in any kind of "corrective action" one should first perform a costbenefit analysis, to make sure which kind of institutional arrangement would maximize social welfare best. It is by no means clear that government action is always required for this purpose. Sometimes its remedies could be even worse than the market "ills" they were supposed to cure. We have to engage in a comparative institutional analysis to avoid this, by discovering the institutional structure that is most likely to minimize the divergence between the theoretical ideal and the real outcomes.

However, notice in the second part of the Demsetz's quotation how he actually accepts the criteria for efficiency concocted by neoclassical theory: "practitioners of this approach (comparative institutional analysis) may use an ideal norm to provide standards from which divergences are assessed for all practical alternatives of interest and select as efficient that alternative which seems most likely to minimize the divergence" (Demsetz, ibid). So, perfect competition is not only a theoretical model that helps to elucidate how a decentralized economic system could provide economically efficient outcomes, but also a benchmark for assessing the alternative possible institutional frameworks and 
their economic effects. Far from rejecting the norm of free ex-ante availability of information as a description of how efficient markets work, Demsetz actually, similarly to Stiglitz, widens the scope of its application, applying the norm to both markets and government. A Pareto optimal or Kaldor-Hicks efficient government action is still a real possibility, although somewhat empirically less likely than for Stiglitz and company.

It could be said therefore that Demsetz throws over the assumption of government superiority, only to smuggle it back again into the model through the back door of "comparative institutional analysis". The government expert is still there: he is not capable anymore of correcting every market failure he sees but is nevertheless accomplished enough to estimate whether he would be able to do so or not! And his word is still final. $\mathrm{He}$ is the one in charge of making the final decision as to what institutional structure is best at optimizing economic outcomes; in other words, he and his fellow bureaucrats determine whether the political costs of using government exceed the market "costs" or not. In a sense, his knowledge and omnipotence are even greater than ever before, because he internalized Socratic wisdom; he is now aware of the limits of his powers, and he wisely refrains from intervention in the cases when his expert knowledge reached through his "comparative institutional analysis" tells him that a market solution would be less costly. The difference between Stiglitz' s "Pareto optimal government intervention" and Demsetz's "comparative institutional analysis" is hence more rhetorical and stylistic, rather than real.

What is the single most important theoretical assumption that Demsetz's nirvana model has in common with all conventional market failure theories? It is that the relative costs of government action and market provision are assumed to be objectively measurable ex-ante by an outside observer. He explicitly formulates this assumption: "Whether the free enterprise solution can be improved upon by the substitution of the government or other non-profit institutions in the financing of research cannot be ascertained solely by examining the free enterprise solution. The political or non-profit forces that are substituted for free enterprise must be analyzed, and the outcome of the workings of these forces must be compared to the market solution before any such conclusions can be drawn" (Demsetz, ibid: 2).

This Demsetzian concept of objectively measurable comparative costs of different institutional settings is no less irreconcilable with the subjective theory of value and price than the market failure theories it purports to criticize. In his book "Cost and Choice", James Buchanan (1969) contends that the cost of an action cannot be apprehended and defined irrespective of an action that is undertaken; it is only an actor, and even him just in a situation of choice, who can know what the true opportunity cost of an action is. Buchanan, in this way, summarizes his subjective theory ${ }^{23}$ of cost:

\footnotetext{
${ }^{23}$ States Hayek $(1979,52)$ : "And it is probably no exaggeration to say that every important advance in economic theory during the last hundred years was a further step in the consistent application of subjectivism." Also, see the following on this issue: Barnett, (1989); Block (1988); Buchanan and Thirlby (1981); Buchanan (1969, 1979); Butos and Koppl (1997); Callahan (2001); Cordato (1989); DiLorenzo (1990); Garrison (1985); Gunning (1990); Kirzner (1986); Mises,
} 
"1. Most importantly, cost must be borne exclusively by the decision-maker; it is not possible for the cost to be shifted to or imposed on others.

2. Cost is subjective; it exists in the mind of the decision-maker and nowhere else.

3. Cost is based on anticipations; it is necessarily a forward-looking or ex-ante concept.

4. Cost can never be realized because of the fact of choice itself: that which is given up cannot be enjoyed.

5. Cost cannot be measured by someone other than the decision-maker because there is no way that subjective experience can be directly observed.

6. Finally, the cost can be dated at the moment of decision or choice." (Buchanan, 1969: 41)

All those points on Buchanan's "list" directly clash with the Demsetzian theory of comparative analysis: if "cost must be borne exclusively by the decision-maker" (Buchanan), how then an objective analyst who is trying to "minimize the divergence" between the theoretical ideal and the real economic outcomes, establish what is the least costly alternative from the point of view of "society" (Demsetz)? Further, if cost is really an anticipative category and cannot be realized apart from the mind of a decision-maker at a specific point of time; in other words, if "what is given up cannot be enjoyed" (Buchanan) - how then can an analyst measure the "enjoyment" of what has already been given up? How can he "compare" the cost of a market outcome with the one that the hypothetical NGO or government provision would bring about? This Demsetzian economist would have to know all the relevant properties of the various counter-factual states of affairs to be able to make such a decision! If so, he would have all the necessary prerequisites to be an efficient central planner. Why not abolish markets altogether then? If, finally, cost represents a "subjective experience", and subjective experience "cannot be observed" (Buchanan), how then can a Demsetzian analyst have fancied himself to be able to observe, "objectivize," these various subjective costs, and moreover, to compare them and even quantify, in order to make sure which one of the opportunities available (market, government, non-governmental organization provision) is best at minimizing the divergence between the model and outcomes?

The common assumption that Demsetz shares with the proponents of market failure theories is that subjective preferences of producers and consumers should and could be modeled as independently existing utility functions. Information about the alternative institutional arrangements must be at least in principle be objectively given - how otherwise could a comparative institutional analysis proceed? In his article "Order Defined in the Process of its Emergence" Buchanan (1982) explains that all attempts to derive the justification for remedial government action from any notion of objectively given information about the utility functions individuals possess faces the following challenge:

"Individuals do not act to maximize utilities described in independently existing functions. They confront genuine choices, and the sequence of decisions taken may be con-

(1998); Rizzo (1979, 1980); Rothbard (1979, 1997a); Stigler and Becker (1977); Stringham (2008); West and McKee (1983). 
ceptualized, ex-post (after the choices), in terms of 'as if' functions that are maximized. But these 'as if' functions are, themselves, generated in the choosing process, not separately from such process. If viewed in this perspective, there is no means by which even the most idealized omniscient designer could duplicate the results of voluntary interchange. The potential participants do not know until they enter the process what their own choices will be. From this it follows that it is logically impossible for an omniscient designer to know, unless, of course, we are to preclude individual freedom of will." (Buchanan, 1982: 12-13).

This is one of the best expositions of why central planning is impossible as well as why any discussion of the comparative efficiency of market vs government solutions is reduced eventually to the socialist central planning argument. Individuals do not maximize their given utility functions but only produce the patterns that ex-post could be described as yielding a utility function. But, the critical point is the fact of unpredictability of individual choices, unpredictability which does not determine only the subjective nature of cost, as Buchanan has already proved, but also the principal incomprehensibility of "information" needed for comparative institutional analysis. What is lacking for such an analysis is the assumption of constancy in human behavior ${ }^{24}$ which must be present in order to functionally model human choices. But as Ludwig von Mises had emphasized, the problem with functional analysis in economics is that everything represents a variable, and constants needed for such analysis are excluded by the very nature of free will and free individual choices. ${ }^{25}$ So, Buchanan drives this deep point home, arguing that only in a world in which individual free will is abolished could the Demsetzian notion of an ex-ante comparative analysis of markets and conscious political design make any sense.

Hayek offered an excellent analysis of the problem of constancy developed in the vocabulary of his "knowledge economics". For him, market competition coordinates a vast amount of production and consumption decisions over time. To say that knowledge about the best ways to produce and consume over time is given ex-ante means no less than to assume the constancy of economic data, i.e. to defeat the very purpose of the process of competition, which is to discover gradually the best ways to satisfy the everchanging needs of consumers. "Competition is essentially a process of the formation of opinion: by spreading information, it creates that unity and coherence of the economic system which we presuppose when we think of it as one market. It creates the views people have about what is best and cheapest, and it is because of it that people know at least as much about possibilities and opportunities as they in fact do. It is thus a process that involves a continuous change in the data and whose significance must, therefore, be completely missed by any theory which treats these data as constant" (Hayek, 1948: 106).

\footnotetext{
${ }^{24}$ Mainstream economists support transitivity. If $\mathrm{A}>\mathrm{B}$, and $\mathrm{B}>\mathrm{C}$, then $\mathrm{A}>\mathrm{C}$. The difficulty is that the first decision is made at time T1, the second at time T2 and the third at time T3. People's taste can change as time elapses. Even if it does not in this case, still, the conclusion of this syllabus by no means follows from the two premises. Team A beats team B. Team B overcomes team C. Can we logically infer that A will outscore C? Of course not.

${ }^{25}$ Ludwig von Mises (1998:55)
} 
The same point was expressed by Ludwig von Mises in a different way, but with the same final results. He maintained not only that costs are subjective, individual, timespecific etc.; the very idea of comparing political and economic costs (upon which the Nirvana theorem is explicitly based) is incompatible with the essence of the dismal science. Economics in the narrower sense, or what Mises called catallactics, is a part of the science of human action. It concerns itself with phenomena of formation of the prices and production structures in a monetary economy ("calculable action") (Mises, 1949). It does not make any sense to talk about the "economic" or catallactic theory of noneconomic phenomena. "Economic analysis" of for example political life is for Mises basically nonsense: "Catalactics is the analysis of those actions which are conducted on the basis of monetary calculation. Market exchange and monetary calculation are inseparably linked together. A market in which there is a direct exchange is merely an imaginary construction" (Mises, 1949: 235).

This has very profound implications, as we take into account that the entire public choice program is based on the assumption that the political process can be analyzed by the tools of economics in the narrower sense, or by Mises, "catallactics". Public choice is replete with talk about "political markets", "political exchange", "costs of government action" and so on and full of attempts to apply price theory to political phenomena. However, we can properly discuss these categories only in a metaphorical way. The idea of a cost-benefit analysis of using markets or government intervention is a category mistake. Completely irrespective of the issue of whether bureaucracy is inefficient, or whether the incentives to act within government are properly aligned, it is impossible to establish a price theory or exchange theory for a non-monetary economy, which the political "market" most decidedly is. Whoever is trying to "compare" the economic costs with the costs of "political action" is comparing apples with oranges. ${ }^{26}$

This argument was implicit even in Mises' early work on socialism (1922) and can best be seen in his treatment of the problem of economic calculation. Mises' objection to public choice is similar to his argument against socialism, which was as follows: let us assume you were able to create a new robotic man ("Homo Sovieticus"), who obeys the orders of his superiors and sacrifices for the common good, instead of pursuing his selfinterest. What are the socialist central planners going to tell him to do, in the absence of prices for the factors of production, and without the ability to classify an investment as good or bad? The same applies to the public choicers' so-called critique of market failure doctrines. Let us assume you succeeded in eliminating all the political bottlenecks,

\footnotetext{
${ }^{26}$ Yet, public choice (and not only public choice) is doing exactly that all the time: moreover, it assumes not only that the concepts of price and costs, but also entrepreneurship, capital and many other concepts of pure economic theory, could be used outside the scope of catalactics. And used, as it were, not only in a very loose, descriptive and metaphorical manner, but as the analytically precise, "exact" (in the Mengerian sense), categories of social theory (We owe this point to Peter Klein). In politics, government owns the means of production (Mises, 1951). Here, no prices can be generated, since there are not markets. But the scholars of the public choice school purport to measure costs which emanate from the political, not the economic system. They are trying to eat their cake and have it too. They attempt to measure costs in the political sphere, when such calculations are only compatible with purely economic markets.
} 
irrationalities of voters, rent-seeking, logrolling, the selfishness of politicians and bureaucracy, and all other "political costs". What is your heroic, "efficient," public servant going to do to maximize "social welfare'? How high should he set the externality tax on the sulphur emission in a perfect world without "political frictions"? What is an "optimal level" of military "public goods" in this perfect world? What about public roads? How many miles of them are to be built, and which routes are to be used? How would your political optimizer know, in the absence of price evaluation of his actions, and a profit and loss weeding out process, whether he succeeded in bringing about the "social optimum" or not? His actions would be no less "a leap in the dark" than those of a socialist central planner.

\section{Coase and consequences}

These untenable assumptions of objectively measurable cost become even more highlighted when we analyze the so-called Coase (1960) theorem and the ways it influenced government failure theories. This theory is important because it enjoys the unquestionable reputation as the ultimate free-market response to the doctrine of externality. What is the most common understanding of Coase's contribution? It is that he proved that the previous arguments about the necessity of government intervention to smooth out externalities were unjustified because the parties involved could better handle it via the process of free-market negotiations (Hanley, Shogren and White 2001, 157; Russell 2001, 46; Friedman, 1986).

This understanding is untenable for the same reasons, as is Demsetz's Nirvana fallacy argument. ${ }^{27}$ On the one hand, Coase indeed attempted to show that the conventional Pigouvian theory of externalities did not provide us with a valid mechanism of wealth maximization and that it should be discarded as such (Coase, 1960). But, he never even tried to prove that the free market will be a more efficient way of eliminating externalities. On the contrary, he concluded that the judges should be substituted for government bureaucrats as wealth-optimizers (Coase, ibid., Demsetz 2011). ${ }^{28}$

The basis of Coase's objection was that Pigou, as all other neoclassical economists did, started from the zero transaction cost assumption. However, if transaction costs were really zero, then no government intervention would have been required since the parties involved would easily negotiate the property transfer that would maximize wealth (Coase, 1960). The market would allocate resources properly. If a person with an inferior ability to maximize the value of an asset ends up holding the ownership over it, another, more capable person, ${ }^{29}$ would be able to buy the asset out of future revenue streams he expects to draw by using the asset in a more efficient way than the current

\footnotetext{
${ }^{27}$ For critiques of Demsetz's $(1979,1997)$ defense of Coase (1960), see Block (1977, 1995, 2000B).

${ }^{28}$ Actually, the free market challenge to Pigou came not from Coase, but from Ludwig von Mises (1949: 650-656) and Frank Knight (1924), both of whom argued that the problem of externalities does not originate from market failure, but from the failure of government to enforce private property rights. Also see Rothbard (1982) in this regard.

${ }_{29}$ "Capable" in the sense of valuing it more.
} 
owner does (Demsetz, 2011). Therefore, how the judges assign the property titles would not matter for wealth maximization, because the market transaction with the property in question is wealth-maximizing by definition.

One problem is that this setting is not how the real-world functions. ${ }^{30}$ In a real-world of positive transaction costs it matters, crucially, how the property rights are assigned because there the high transaction costs will prevent the beneficial rearrangements of property titles from ever taking place. A less efficient owner is awarded the control over an asset, but the more efficient one may not be able to buy it due to the high costs of transferring property rights. And, as Coase himself argued, this is the only case that is really interesting and theoretically relevant. Therefore, his famous "theorem" was not meant to be a free market critique of government interventionism at all. It was rather a call to the economics profession to abandon the artificial assumption of zero transaction costs and analyze the real world of positive transaction costs.

What should be done in the world of high transaction costs? The judges, according to Coase, should take responsibility for maximizing welfare by redistributing the property rights in a way that would be most likely to maximize overall societal wealth. For this purpose, of course, it does not matter who is a legal title holder; the very category of ownership is in Coase's view "reciprocal". The task of judicial intervention should be not to enforce any pre-existing pattern of the allocation of property rights, but to attain and preserve economic efficiency, whatever that might mean in terms of rearranging the distribution of property rights: "The problem which we face in dealing with actions which have harmful effects is not simply one of restraining those responsible for them. What has to be decided is whether the gain from preventing the harm is greater than the loss which would be suffered elsewhere as a result of stopping the action which produces the harm. In a world in which there are costs of rearranging the rights established by the legal system, the courts, in cases relating to nuisance, are, in effect, making a decision on the economic problem and determining how resources are to be employed." (Coase, 1960:11)

It turns out that the task of a Coasean judge should be to supplant, e.g., override, market forces in allocating resources. This is quite similar to the task, Pigou, Stiglitz, and Samuelson assign to government bureaucrats - to find an optimal economic solution to overcome the failure of the price system to reflect the underlying scarcities of goods. The paradox is that although in this model zero transaction costs and perfect information did not exist anymore, judicial intervention is expected to bring about exactly the state of affairs that would have prevailed if they had really existed! The judges should emulate or mimic the markets, as best they can.31 As Block puts it: "In Coase's

\footnotetext{
${ }^{30}$ Another difficulty is that this Coasean analysis assumes that the person who more highly values the item under dispute has the wherewithal to bribe his legal opponent into giving it to him. This holds true even in the zero transactions cost world, if the judicial ruling goes against him. See on this Block (1977).

${ }^{31}$ Notice how Coase's notion of efficient free markets is the polar opposite of Hayek's: instead of saying that market competition exists in order to discover the more efficient ways of doing things that we do not know how to do ex ante, Coase contends that since no such
} 
view, proper law consists of figuring out what the free enterprise system would have done in the absence of transaction costs, and then imposing this result on people in the real high-transaction cost world" (Block, 2003A: 926).

If this sounds a lot like "market socialism" that is probably because it is. The idea that wealth can be maximized by experts irrespective of the regime of property rights and legal rules was at the center of all the attempts of some authors to construct an amalgamated "market socialist" system which would combine some form of prices along with government ownership of the means of production (Bergson, 1948, Lange and Taylor, 1938). For Coase as well, wealth maximization is "institutionally elastic" - we do not have to specify what kind of economic and political system we are talking about to accept the possibility of judicial wealth optimization within it. But this is a mistake, as Gerald O'Driscoll (1980: 357) nicely points out: "Utility or wealth maximization presupposes a prior rights distribution and given rules, legal and otherwise. Maximization makes sense if we know who has what rights, and what rules govern the choice process. The suggestion that the maximization principle be used to determine the rights distribution and the legal rules is almost incoherent".

David Friedman, an influential follower of Coase's, supports the latter's contention that the courts should nevertheless be allowed to make their decisions about externalities in the way Coase prescribes, rather than to allow government to handle it in a more conventional, Pigouvian manner:

"Suppose that, in a particular case, the pollution does $\$ 100,000$ a year worth of damage and can be eliminated at a cost of only $\$ 80,000$ a year (from here on, all costs are per year). Further assume that the cost of shifting all of the lands downwind to a new use unaffected by the pollution-growing timber instead of renting out summer resorts, say-is only $\$ 50,000$. If we impose an emission fee of a hundred thousand dollars a year, the steel mill stops polluting and the damage is eliminated - at a cost of $\$ 80,000$. If we impose no emission fee the mill keeps polluting, the owners of the land stop advertising for tenants and plant trees instead, and the problem is again solved - at a cost of $\$ 50,000$. In this case, the result without Pigouvian taxes is efficient - the problem is eliminated at the lowest possible cost — and the result with Pigouvian taxes in inefficient." (Friedman, 2000)

However, it is not difficult to see why the entire argument does not hold water: it assumes that the judges can objectively asses the monetary costs of different future states of affairs, the same ability Pigou ascribed to government bureaucrats. But both assumptions are equally arbitrary and fallacious; the judge cannot know who is the "optimal cost avoider" no more than could the conventional Pigouvian government planner know the "optimal" level of the externality fee. Why is it reasonable to assume that courts and

perfect information about the optimal ways of doing things exists (transaction costs are high) then judges must intervene in order to optimize the operation of the markets. For Hayek, the less perfect the knowledge is, the more we need the market. For Coase, the less knowledge we have, the less we should use the market. The optimal knowledge about the resource allocation for him is not the result but the precondition for efficient functioning of markets. In terms of resource allocation and economic freedom, see Gwartney, et al. (1996, 2000, 2003, 2007, 2011, 2018, 2019). 
judges ${ }^{32}$ have a comparative advantage over other types of government regulators in anticipating the most efficient ways of allocating the production factors in the future? Only the place of the magical transformation of the imperfect reality into the Pareto optimal nirvana has changed (meaning, the type of bureau or office in charge of "optimization"). But the ideal remains the same - an extra-market expert who manages the world according to his "superior" knowledge. Ironically, Friedman seems to be aware of this problem of competence, but only in the case of Pigou: "Pigou's solution is correct only if the agency making the rules already know which party is the lowest cost avoider" (Friedman, ibid.). But, for some strange reason, he is unaware of the obvious fact that exactly the same objection can be made against Coase's judges.

Coase's conclusions closely dovetail with those of Demsetz; the latter emphasizes the same two important factors that Demsetz singled out as the essence of his "comparative institutional" method; on the one hand, faith in the possibility to objectively measuring social costs, and on the other a cautious, "pragmatic" approach to government intervention. It is even possible to say that Coase anticipates Demsetz's nirvana model. Here is what the former writes: "Economists who study problems of the firm habitually use an opportunity cost approach and compare the receipts obtained from a given combination of factors with alternative business arrangements. It would seem desirable to use a similar approach when dealing with questions of economic policy and to compare the total product yielded by alternative social arrangements" (Coase, 1960: 21). Coase assumes it is possible to make an ex ante cost-benefit analysis so as to eliminate externalities, in the same manner that entrepreneurs use opportunity cost to allocate resources among the intra-firm production and market purchases. However, the critical difference that makes the entire scheme specious is that an entrepreneur operates in an environment of private property rights and genuine prices, so he can evaluate his actions by profit or loss. What is the judge's benchmark in assessing the optimality of his decisions? Except for such vague formulations as "compare the total product yielded by alternative social arrangements" Coase does not give us much guidance. We remember again Buchanan's warning that utility functions do not exist ex-ante, and that all cost-benefit analysis of fictitious "objective costs" is as much a "leap in the dark" as it is the conventional socialist central planning.

Moreover, if we assign to judges the power to maximize wealth by their decisions in cases involving disputes over property rights, why not give them the power to do the same thing in other cases that did not involve any dispute? Why not reassign property rights daily to maximize efficiency? For example, why not confiscate the savings of many poor clerks or janitors and give them to, say, Bill Gates or Warren Buffet? If a judge estimates that it is highly likely that the "total product yielded" would thus probably be immensely increased, there is no the slightest justification from the Coasean point of view to deprive Gates and Buffet of their redistributed property titles and society of its "maximization of wealth" ${ }^{33}$ Again, if this seems exaggerated,${ }^{34}$ we need to

\footnotetext{
${ }^{32}$ Or, even private ones, in the absence of markets.

${ }^{33}$ In the paper "Coase and Kelo", Walter Block (2006) explains that the judges already apply this Coasean reasoning. In a high profile case "Kelo vs City of New London" the Supreme court
} 
know why is it exaggerated - at which point down the road to socialism a Coasean judge losses his ability to determine a "cost-minimizing" solution better than private actors?

It is important to note that in a theoretical sense, Coasean and Demsetzian schemes do not rely necessarily on the conventional Pareto optimum, but on a slightly modified, but equally untenable ideal - so-called Kaldor-Hicks efficiency. ${ }^{35}$ According to one of the principal followers of Coase, Richard Posner, the Kaldor-Hick's efficiency means that "Resources are allocated efficiently in a system of wealth maximization when there is no reallocation that would increase the wealth of society" (Posner, 1980: 491). This criterion resembles Pareto optimality but has one advantage over it in the view of its proponents: it does not use interpersonal comparisons of utility but is entirely based on the people's willingness to pay in real money terms. ${ }^{36}$ It concerns itself with maximization of monetary wealth, rather than with maximization of utility or "social welfare". Although the Coasean judicial optimization does not include compensation to the victims, it embraces the same kind of concerns with monetary wealth maximization.

There are many difficult problems, even with this modified criterion of optimal reallocation of resources. For the most part it just replicates the same errors embedded in using the Pareto rule as the benchmark of public policy. First, how would a judge estimate the actual willingness of different people to pay? People's preferences, and therefore their willingness to pay any amount of money for any good or service are demonstrated only through their actions on the market, in other words through acts of voluntary buying and selling (Rothbard, 1956). The fact that a person A was ready to pay an amount X of dollars for some service at the moment of time 1 does not mean that he will be ready to pay the same amount for the same service at moment 2 . The scales of preferences are not constant, the valuations always change over time, and to use frozen valuations from the past as a guide for making policy in the future is erroneous (Roth-

confiscated the private property of a person and assigned it to a corporation, using the explicit argument that social welfare would be maximized that way ("economic development in the Courts' parlance), and that way, according to Block, merely applied the Coasean criterion of "wealth maximization".

${ }^{34}$ That is the whole point of the reductio ad absurdum objection. To utilize the precise logic of the target, and apply it to a case where even he will blanch, hopefully, at the result.

35 Actually the range of application of this criterion is much wider: apart from the judicial area, Kaldor-Hicks is used in cost-benefit analysis of government programs etc. See Posner, (2000: 1153-56).

${ }^{36}$ It is interesting that Coase (1960) in "The problem of Social Costs" concedes that his approach was similar to that of Kaldor-Hicks efficiency, but adds that this was unsatisfying, and that the old fashioned welfare economics should be revived: "In this article, the analysis has been confined, as is usual in this part of economics, to comparisons of the value of production, as measured by the market. But it is, of course, desirable that the choice between different social arrangements for the solution of economic problems should be carried out in broader terms than this and that the total effect of these arrangements in all spheres of life should be taken into account" (Coase, 1960: 21). Munger (2010: 117) asserts that Coase's bargaining and Kaldor-Hicks are "isomorphic", (isomorphic = having the same form) but that the Coasean approach is less intrusive and coercive. However, Munger does not analyze the parallels that exist between the judicial wealth-optimization and Kaldor-Hicks compensations. 
bard, ibid). As Ludwig von Mises explained, prices are always past prices. It does not make sense to try to infer an optimal policy of "compensation," or anything else, in the future, based on the historical snapshots of prices paid in the past. ${ }^{37}$ So, it is impossible for an outside observer to define what is the real "willingness to pay" of any other person (Stringham, 2001).

And second, as Munger (2010: 124) points out, Kaldor-Hicks efficiency of necessity includes the assumption of the third-party determination of costs and benefits, which is clearly untenable: "The costs and benefits to individuals can be measured in dollars by an outside observer". This is exactly the same problem that the Coasean judge faces in his attempt to determine which kind of property the right arrangement best provides for the maximization of monetary wealth. He is not concerned with compensating the victims but must nevertheless figure out how to secure the maximum monetary return overall. As Demsetz (2011: 9) emphasizes, this is a perfect way to prevent economically efficient outcomes from ever taking place because the judiciary "simply may have made a mistake because it is not guided in its decisions by a market-based calculus". The only way to allow the parties involved to demonstrate their preferences and thus direct the scarce resources towards the most profitable uses would be to give them a right to bribe the judges. In that way the entire process would emulate the Coasean bargaining in a zero-transaction costs environment, by making it possible for the more able users of resources to acquire them in "legitimate" economic transactions (Demsetz, ibid).

For all those reasons Buchanan's arguments we utilized earlier in criticizing Demsetz's Nirvana theorem equally apply to the Coase theorem. This is irrespective of whether we interpret Coase and Demsetz in the Kaldor-Hicks sense or not: objections based on the divorce of costs from an act of choice, and the objectification of knowledge about individual willingness to act in a certain way, remains intact in the Kaldor-Hicks reformulation of Pareto optimality. The only thing Kaldor- and Hicks achieved was to discard cardinal utility, but that is just a minor and incidental feature of this model. "Willingness to pay" is equally bound to a uniquely individual choice in time and space as utility or psychological opportunity cost. And it is equally divorced from individual choice in the Kaldor-Hicks doctrine as utility was from choice within the older welfare economics tradition.

Another heroic effort to escape the pitfalls of Pareto theory by reconciling welfare economics with the subjectivism of modern price theory was made by Israel Kirzner. His idea of "Austrian welfare economics" also starts off by rejecting classical concept of Pareto optimality, which is replaced by the Hayekian concept of "coordination of activities". Instead of saying that the economic policy should maximize "social welfare" now we aver that it should maximize the level of coordination of activities among economic agents. According to Kirzner, this is from the "Austrian" perspective, and thus much

\footnotetext{
${ }^{37}$ Boudreaux, Mainers and Zywicki (1999: 783) rightly point out: "Prices are not static and absolute. . . . There is no 'willingness to pay' for IBM stock; there is today's price for IBM stock".

${ }^{38}$ The cardinal-ordinal divergence is crucially important, however, in many other contexts, such as in welfare economics; see on this Rothbard (1957).
} 
better since it is not contrary to the assumptions of subjectivism and methodological individualism. What society loses by economic 'discoordination' is not some mythical cardinally calculated "objective welfare" but subjectively measured personal loses of possible grains from trade (Kirzner, 1992: 180-190)

Yet, this is of no great help either. If we take seriously Hayek's theory of knowledge and its use in the economy - the theory on which Kirzner bases everything - then we still have no more justification in setting "increase in coordination" as the chief welfare economic desideratum than the previous "increase in social welfare". How can we distinguish between two market regimes or two different economic policies regarding the degree of coordination they allow? To do so, we would have to know beforehand the "optimal level of coordination" and then compare the two empirical results with this theoretical optimum. And to do so we would need to know everything about the particular situations of every market agent about whom we proudly confess ex-ante, together with Hayek, we don't know anything. Hence this Kirznerian seemingly fallibilistic retreat from Pareto optimality to subjectivistic "plan coordination" is a mirage: both equally require, and both are equally irreconcilable with Hayekian notions of knowledge and its use in society.

\section{Conclusion}

This paper showed that the Mises impossibility theorem is equally applicable to socialism as well as to any attempt to overcome so-called market failure. It is irreconcilable with the conventional theories of market failure that hypothesize Pareto optimal government intervention. In order to make the required sort of cost-benefit analysis, the government agents should have the epistemic abilities of supposedly expert socialist central planners, and the entire subjectivist theory of value and cost would have to be abandoned. By analyzing the prominent formulations of government failure theory as developed in the public choice and law and economics traditions, we conclude that they are based on the same erroneous theories of objectively knowable and measurable values and costs, and the same misapprehension what constitutes efficient markets.

Acknowledgments: We acknowledge and thank two anonymous referees of this journal for constructive criticism. The paper is much improved due to their contribution. However, the usual caveats apply: all remaining errors and infelicities are the sole responsibility of the authors, alone.

Disclosure statement: The authors reported no potential conflict of interest.

\section{References}

ALCHIAN, A. A., DEMSETZ, H. (1972). Production, Information Costs, and Economic Organization, The American Economic Review Vol. 62, No. 5 (Dec., 1972), pp. 777-795.

AKERLOF G. A. (1970). The Market for "Lemons": Quality Uncertainty and the Market Mechanism, The Quarterly Journal of Economics, Vol. 84, No. 3. (August), pp. 488-500. 
ANDERSON, W. L. (2001). Lemons and the Nobel Prize. Accessed on October 11 from https://mises.org/library/lemons-and-nobel-prize

ANDERSON, W. L. (2018). Sorry, Stiglitz: It's Socialism That's Rigged — not Capitalism. Accessed on November 14 from https://mises.org/wire/sorry-stiglitzit $\%$ E2\%80\%99s-socialism-\%E2\%80\%99s-rigged-\%E2\%80\%94-not-capitalism

ARMENTANO, D. T. (1982). Antitrust: Anatomy of a Policy Failure, New York, John Willy and Sons.

BERGSON, A. (1948). Socialist Economics, in H.S. Elis ed., A Survey of Contemporary Economics, Philadelphia, Blakiston.

BARNETT, W., BLOCK, W. E. (2007). Coase and Van Zandt on Lighthouses, Public Finance Review, Vol. 35, No. 6, November, pp. 710-733. DOI: $\underline{10.1177 / 1091142107302182}$

BARNETT, W., BLOCK, W. E. (2009). Coase and Bertrand on Lighthouses, Public Choice; 140(1-2):1-13, http://dx.doi.org/10.1007/s11127-008-9375-X

BHAGWATI, J. N. (1982). Directly unproductive, profit-seeking (DUP) activities. Journal of Political Economy. Vol. 90, No. 5, p. 988-1002. DOI: 10.1086/261104

BLOCK, W. E. (1977). Coase and Demsetz on Private Property Rights, The Journal of Libertarian Studies: An Interdisciplinary Review, Vol. I, No. 2, 1977, pp. 111-115;

BLOCK, W. E. (1983). Public Goods and Externalities: The Case of Roads, The Journal of Libertarian Studies: An Interdisciplinary Review, Vol. VII, No. 1, Spring, pp. 134; http://www.mises.org/journals/jls/7_1/7_1_1.pdf

BLOCK, W. E. (1988). Comment on Leland Yeager on Subjectivism, Review of Austrian Economics, Vol. II, pp 199-208; http://www.mises.org/journals/rae/pdf/r2_12.pdf

BLOCK, W. E. (1995). Ethics, Efficiency, Coasean Property Rights and Psychic Income: A Reply to Demsetz, Review of Austrian Economics, 8 (2): 61-125, http://www.mises.org/journals/rae/pdf/rae8_2_4.pdf

BLOCK, W. E. (2000a). Watch Your Language, Accessed on February 21 from http://mises.org/daily/385

BLOCK, W. E. (2000b) Private Property Rights, Erroneous Interpretations, Morality and Economics: Reply to Demsetz, Quarterly Journal of Austrian Economics, Vol. 3, No. 1, Spring, pp. 63-78; http://www.mises.org/journals/qjae/pdf/qjae3_1_8.pdf

BLOCK, W. E. (2003a). Private Property Rights, Economic Freedom, and Professor Coase: A Critique of Friedman, McCloskey, Medema, and Zorn, Harvard Journal of Law \& Public Policy, Vol. 26(3), pp. 923-951.

BLOCK, W. E. (2003b). National Defense and the Theory of Externalities, Public Goods and Clubs., in HOPPE, H. H. (ed.). The Myth of National Defense: Essays on the Theory and History of Security Production. Auburn: Mises Institute, pp. 301-334; http://www.mises.org/etexts/defensemyth.pdf 
BLOCK, W. E. (2005). Government and Market: A Critique of Professor James Buchanan's What Should Economists Do?. Corporate Ownership \& Control, Vol. 3, No. 1, Fall, pp. 81-87; http://tinyurl.com/38ul71

BLOCK W. E. (2006). Coase and Kello: Omnius Parallels and Reply to Lott on Rothbard", Whittier Law Review, Volume 27, no. 4: 997-1023.

BLOCK, W. E. (2008, [1976]). Defending the Undefendable. Auburn, AL: The Mises Institute

BLOCK, W. E. (2015). The rent seeker. Romanian Economic and Business Review, Vol. 10, No. 3, pp. 7-14, Fall; http://www.rebe.rau.ro/REBE_10_3_2015.pdf

BLOCK, W., DILORENZO, T. J. (2000). Is Voluntary Government Possible? A Critique of Constitutional Economics, Journal of Institutional and Theoretical Economics, Vol. 156, No. 4, December, pp. 567-582; http://www.walterblock.com/publications/voluntary_govt.pdf

BLOCK, W., DILORENZO, T. J. (2001). "The Calculus of Consent Revisited," Public Finance and Management, Vol. 1, No. 3; electronic journal, http://spaef.com/PFM_PUB/v1n3/1_3/1_3_3_block.html

BLOCK, W., GARSCHINA, K. M. (1996). Hayek, Business Cycles and Fractional Reserve Banking: Continuing the De-Homoginization Process, Review of Austrian Economics, Vol. 9, No. 1, 1995, pp. 77-94; DOI: 10.1007/BF01101882

BLOCK, W. E., NELSON, P. L. (2015). Water Capitalism: The Case for Privatizing Oceans, Rivers, Lakes, and Aquifers. New York City, N.Y.: Lexington Books, Rowman and Littlefield

BOETTKE P. J., COYNE, CH., J., LEESON, P. T. (2007). Saving Government Failure Theory from Itself: Recasting Political Economy from an Austrian Perspective, Constitutional Political Economy, no 18: pp. 127-143. DOI: 10.1007/s10602-007-9017-1

BOUDREAUX, D., MEINERS, R., ZYWICKI, T. (1999). Talk is Cheap: The Existence Value Fallacy. Environmental Law 29(4): 765-809.

BUCHANAN J. (1969). Cost and Choice: An Inquiry in Economic Theory, Collected Works of James Buchanan, Volume 6, Liberty Fund Indianapolis.

BUCHANAN, J. (1979). The General Implications of Subjectivism in Economics, in What Should Economists Do?, Indianapolis: Liberty Press

BUCHANAN J. (1982). Order Defined in the Process of its Emergence, [A note stimulated by reading Norman Barry, "The Tradition of Spontaneous Order," Literature of Liberty, V (Winter 1982), 12-13.]

BUCHANAN, J. M., THIRLBY, G. F. (1981). L.S.E. Essays on Cost, New York: New York University Press.

BUCHANAN, J. M., TULLOCK, G. (1962). The Calculus of Consent. Ann Arbor: University of Michigan Press. 
BUTOS, W., KOPPL. R. (1997). The varieties of subjectivism: Keynes, Hayek on expectations. History of Political Economy, 29 (2), pp. 327-59. DOI: 10.1215/0018270229-2-327

CALDWELL, B. (1997). Hayek and Socialism. Journal of Economic Literature, Vol. XXXV (December), pp. 1856-1890.

CALlAHAN, G. (2001). De Gustibus Non Est Disputandum., Accessed on April 27; from http://mises.org/daily/666.

CAPLAN, B. (2007). The Myth of the Rational Voter: Why Democracies Choose Bad Policies. Princeton, N.J.: Princeton University Press.

COASE, R. H. (1937). The Nature of the Firm, Economica, November, Vol. 4, pp. 386406. DOI: $10.1111 / \mathrm{j} .1468-0335.1937 . t b 00002 . x$

COASE, R. H. (1960). The Problem of Social Cost, Journal of Law and Economics, 3: $1-44$.

COASE, R. H. (1988). The Nature of the Firm, The Firm, the Market, and the Law, Chicago: University of Chicago Press.

CORDATO, R. E. (1989). Subjective Value, Time Passage, and the Economics of Harmful Effects, Hamline Law Review, Vol. 12, No. 2, Spring, pp.229-244.

COWEN, T. (ed). (1988). The Theory of Market Failure: A Critical Examination, Fairfax, VA: George Mason University Press.

COWEN T., CRAMPTON, E. (2002). Market Failure or Success. The new Debate. Edward Elgar Publishers.

DE JASAY, A. (1989). Social Contract, Free Ride: A Study of the Public Goods Problem. Oxford, England: Oxford University Press.

DEMSETZ, H. (1969). Information and Efficiency: Another Viewpoint, Journal of Law and Economics, Vol. 12, No. 1 (Apr., 1969), pp. 1-22. DOI: 10.1086/466657

DEMSETZ, H. (1979). Ethics and Efficiency in Property Rights Systems, In RIZZO. M. (ed.). Time, Uncertainty and Disequilibrium: Explorations of Austrian Themes, Lexington Mass.: D.C. Heath and Co; http://mises.org/Books/timeuncertainty.pdf (see chapter 5)

DEMSETZ, H. (1997). Block's Erroneous Interpretations, Review of Austrian Economics, Vol. 10, No. 2, pp. 101-109; DOI: 10.1007/BF02538487

DEMSETZ, H. (2011). The Problem of Social Cost: What Problem? A Critique of the Reasoning of A.C. Pigou and R.H. Coase, Review of Law and Economics, 7:1.

DILORENZO, T. J. (1984). The Domain of Rent-Seeking Behavior: Private or Public Choice?, International Review of Law and Economics, December. DOI: 10.1016/0144$\underline{\text { 8188(84)90005-X }}$

DILORENZO, T. J. (1987). Competition and Political Entrepreneurship: Austrian Insights into Public Choice Theory, Review of Austrian Economics, Fall; http://mises.org/journals/rae/pdf/RAE2_1_3.pdf 
DILORENZO, T. J. (1988). Property Rights, Information Costs, and the Economics of Rent Seeking, Journal of Institutional and Theoretical Economics, Spring

DILORENZO, T. J. (1990). The Subjectivist Roots of James Buchanan's Economics, Review of Austrian Economics, Vol. 4, pp. 180-195, Spring; DOI: 10.1007/BF02426367

DILORENZO, T. J. (2002). George Stigler and the Myth of Efficient Government, Journal of Libertarian Studies, Fall.

DILORENZO, T. J. (2011). A Note on the Canard of 'Asymmetric Information' as a Source of Market Failure. Quarterly Journal of Austrian Economics, Vol. 14, No. 2, 249-255, Summer; http://mises.org/journals/qjae/pdf/qjae14_2_6.pdf

DILORENZO, T. J., BLOCK, W. E (2001). Constitutional Economics and the Calculus of Consent, The Journal of Libertarian Studies, Vol. 15, No. 3, Summer, pp. 37-56; http://www.mises.org/journals/jls/15_3/15_3_2.pdf

DILORENZO, T. J., BLOCK, W. E. (2016). An Austro-Libertarian Critique of Public Choice; Addleton Academic Publishers; www.addletonacademicpublishers.com; 30-18 50th Street, Woodside, New York.

EBELING, R. (1992). Introduction. In R. EBELING, (ed.) The Global Failure of Socialism. Hillsdale, MI: Hillsdale College Press, pp. 6-8.

EBELING, R. (2017). Capitalism and Asymmetric Information. Accessed on December 5 from https://mises.org/wire/capitalism-and-asymmetric-information.

FAMA, E. (1980). Agency Problems and the Theory of the Firm, The Journal of Political Economy, Vol. 88, No. 2. (Apr., 1980), pp. 288-307. DOI: $\underline{10.1086 / 260866}$

FOX, G. (2017). Asymmetric Information and Market Failure: A Market Process Perspective. Accessed on March 13 from https://mises.org/library/asymmetric-informationand-market-failure-market-process-perspective

FRIEDMAN D. (2000). Swedes Get it Right, Accessed form https://msu.edu/course/ec/360/Matraves/coase.htm.

FRIEDMAN, M. (1962). The Role of Government in Education, Capitalism and Freedom, Chicago IL: University of Chicago Press

GARRISON, R. (1985). A Subjectivist Theory of a Capital Using Economy, in O'DRISCOLL, G. P., RIZZO, M. (Eds.), The Economics of Time and Ignorance, Oxford: Basil Blackwell

GREENWALD, B., STIGLITZ, J. E. (1986). Externalities in economies with imperfect information and incomplete markets. Quarterly Journal of Economics 101: 229-264. DOI: $10.2307 / 1891114$

GUNNING, J. P. (1990). The New Subjectivist Revolution: An Elucidation and Extension of Ludwig von Mises's Contribution to Economic Theory, Savage, MD: Rowan and Littlefield.

GWARTNEY, J., LAWSON, R., BLOCK, W. E. (1996). Economic Freedom of the World, 1975-1995, Vancouver, B.C.: The Fraser Institute 
GWARTNEY, J., LAWSON R., SAMIDA, D. (2000). 2000 Annual Report: Economic Freedom of the World, Vancouver, B.C.: The Fraser Institute (that anti egalitarian chart, p. 17)

GWARTNEY, J., LAWSON, R. (2003). Economic Freedom of the World: 2003 Annual Report, Vancouver: The Fraser Institute

GWARTNEY, J., LAWSON, R. (2007). Economic Freedom of the World, 2007 Annual Report, Vancouver, B.C.: The Fraser Institute

GWARTNEY, J., LAWSON, R., HALL, J. (2011). Economic Freedom of the World, Vancouver: the Fraser Institute;http://www.freetheworld.com/2011/reports/world/EFW2011_complete.pdf

GWARTNEY, J., LAWSON, R., HALL, J. C., MURPHY, R., CZEGLÉDI, P, MCMAHON, F., FIKE, R., NEWLAND, C. (2018). Economic Freedom of the World: 2018 Annual Report, Vancouver: The Fraser Institute; https://www.fraserinstitute.org/studies/economic-freedom-of-the-world-2018-annualreport

GWARTNEY, J., LAWSON, R., HALL, J. C., MURHPY, R., BENNETT, D. L., MCMAHON, F., FIKE, R., NIKOLAEV, B. (2019). Economic Freedom of the World: 2019 Annual Report. Vancouver: The Fraser Institute; https://www.fraserinstitute.org/studies/economic-freedom-of-the-world-2019-annualreport

HANLEY, N., SHOGREN, J., WHITE, B. (2001). Introduction to Environmental Economics. Oxford: Oxford University Press.

HAYEK, F. A. (1964). Individualism and Economic Order. Chicago: University of Chicago Press.

HAYEK, F. A. (1979). The Counter-Revolution of Science, $2^{\text {nd }}$ ed. Indianapolis, IN: LibertyPress

HAYEK, F. A. (2002). Competition as a Discovery Procedure, The Quarterly Journal of Austrian Economics Vol 5, No. 3 (Fall 2002): 9-23. DOI: 10.1007/s12113-002-1029$\underline{0}$

HAYEK, F. A. (2010). The Meaning of Competition. Accessed on March 15 from http://mises.org/daily/4181

HENDERSON, D. R. (2008). Rent seeking. The concise encyclopedia of economics. In. HENDERSON, D. R., Indianapolis, IN: The Liberty Fund;

http://www.econlib.org/library/Enc/RentSeeking.html

HERBENER, J. M. (1997). The Pareto Rule and Welfare Economics, Review of Austrian Economics, vol.10,no. 1: 79-106. DOI: 10.1007/BF02538144

HERBENER, J. M. (1991). Ludwig von Mises and the Austrian School of Economics. Review of Austrian Economics, Vol. 5, No. 2, pp. 33-50; DOI: 10.1007/BF02426927

HIGGS, R. (2016). Identity Politics, Public Choice, and Ideology. Accessed on December 31 from http://www.targetliberty.com/2016/12/identity-politics-public-choice- 
and.html?utm_source=feedburner\&utm_medium=email\&utm_campaign=Feed $\% 3 \mathrm{~A}+\mathrm{Ta}$ rgetLiberty+\%28Target+Liberty\%29

HOLCOMBE, R. (1997). A Theory of the Theory of Public Goods, Review of Austrian Economics, Vol. 10, No. 1: 1-10; DOI: 10.1007/BF02538141

HOPPE, H. H. (1989). Fallacies of the Public Goods Theory and the Production of Security, The Journal of Libertarian Studies, Vol. IX, No. 1, Winter, pp. 27-46; http://www.mises.org/journals/jls/9_1/9_1_2.pdf.

HOPPE, H. H. (1996). Socialism: A Property or Knowledge Problem? Review of Austrian Economics, 9(1), pp. 147-154; http://mises.org/journals/rae/pdf/RAE9_1_13.pdf

FRIEDMAN D. (1991). The Swedes Get it Right, Reason Magazine. http://www.daviddfriedman.com/Academic/Coase_World.html

HUMMEL, J. (1990). National Goods vs. Public Goods: Defense, Disarmament and Free Riders, The Review of Austrian Economics, Vol. IV, pp. 88-122; http://www.mises.org/journals/rae/pdf/rae4_1_4.pdf

IKEDA, S. (2003). How Compatible are Public Choice and Austrian Political Economy, The Review of Austrian Economics, 16:1, pp. 63-75. DOI: 10.1023/A:1022909308090

JANKOVIC, I. (2010). Firm as a Nexus of Markets. Journal des Economistes et des Etudes Humaines, Vol. 16, no. 1, article 3.

JANKOVIC, I. (2015). Heterogeneous Capital and the Coasean Firm. New Perspectives on Political Economy. Vol 10, no 1, pp. 29-48.

JENSEN, M., MECKLING, W. (1976). Theory of the firm: Managerial behavior, agency costs and ownership structure, Journal of Financial Economics, vol 3, issue 4, pp. 305-360. DOI: $10.1016 / 0304-405 X(76) 90026-X$

KAHN, A. E. (1953). Standards for Antitrust Policy; 67 Harvard Law Review 28.

KIRZNER, I., ed. (1986). Subjectivism, Intelligibility and Economic Understanding, New York: New York University Press

KIRZNER, I, ed. (1992). The Meaning of Market Process. New York: Routledge

KIRZNER, I. M. (1996). Reflections on the Misesian Legacy in economics. Review of Austrian Economics. Vol. 9, No. 2, pp. 143-154; DOI: 10.1007/BF01103334

KNIGHT, F. H. (1924). Some Fallacies in the Interpretation of Social Cost, Quarterly Journal of Economics, 38, 582-606.

KNOTT, A. (2012). Hayek and Praxeology. Accessed on November 13 from http://www.mises.org/daily/6248/Hayek-and-Praxeology

LANGE, O., TAYLOR, F. M. (1938). On the Economics Theory of Socialism. University of Minnesota Press, Minneapolis.

LEWIN, P., PHELAN, S. (1999). Firms, Strategies, and Resources. Quarterly Journal of Austrian Economics 2, no. 2: 1-18.; http://mises.org/journals/qjae/pdf/qjae2_2_1.pdf 
MACCALLUM, S. H. (2015). Freedom's Ugly Duckling: A Fresh Take on Property in Land. Libertarian Papers. Vol. 7.

MACHOVEC, F. M. (1995). Perfect Competition and the Transformation of Economics. Routledge.

MACKENZIE, D. W. (2003). Markets and the Information Problem. Accessed on January 7 from https://mises.org/library/markets-and-information-problem

MACKENZIE, D. W. Unpublished. Politics and Knowledge: Expectations Formation in Democracy.

MCCHESNEY, F., SHUGART, W. (1995). The Causes and Consequences of Antitrust: The Public-Choice Perspective. Chicago: University of Chicago Press.

MISES, L. von ([1922] 1981). Socialism: An Economic and Sociological Analysis. Translated by J. Kahane. Indianapolis: Liberty Fund.

MISES, L. von. (1949). Human Action. The scholars edition, Ludwig von Mises Institute, Alabama.

MISES, L. von. (1951). Socialism: An Economic and Sociological Analysis. New Heaven: Yale University Press.

MISES, L. von. (1969). Bureaucracy, New Rochelle, N.Y.: Arlington House; http://www.mises.org/Literature/search/?q=Bureaucracy;

MISES, L. von. (1990). Economic Calculation in the Socialist Commonwealth, Ludwig von Mises Institute, Alabama.

MICHAEL M. (2010). Kaldor-Hicks Coercion, Coasian Bargaining, and the State." In MARTINEZ, J. WINER, S. (eds.), Coercion and Social Welfare in Public Finance: Economic and Political Dimensions, conference volume for Evergreen Resort Coercion Conference, Oct. 1-2, 2010. Cambridge University Press. Pp. 117-135

NELSON, P. L., BLOCK, W. E. (2018). Space capitalism: the case for privatizing space travel and colonization. Palgrave Macmillan

NISKANEN W. (1971). Bureaucracy and Representative Government. Chicago: Aldine-Atherton.

O'DRISCOLL, G. (1980). Justice, Efficiency, and the Economic Analysis of Law: A Comment on Fried. Journal of Legal Studies 9:355-66.

OSTERFELD, D. (1989). Anarchism and the Public Goods Issue: Law, Courts and the Police, The Journal of Libertarian Studies, Vol. 9, No. 1, Winter, pp. 47-68; http://www.mises.org/journals/jls/9_1/9_1_3.pdf

PASOUR, E. C., Jr., (1981), The Free Rider as a Basis for Government Intervention, The Journal of Libertarian Studies, Vol. V, No. 4, Fall, pp. 453-464; http://www.mises.org/journals/jls/5_4/5_4_6.pdf

PASOUR, E. C., Jr. (1986). Rent Seeking: Some Conceptual Problems and Implications. Review of Austrian Economics 1: 123-43; DOI: 10.1007/BF01539337 
PERITZ, R. (1996). Competition Policy in America, 1888-1992. Oxford University Press.

PIGOU, A. C. (1932). Economics of Welfare. London: Macmillan and Co.

POSNER, R. A. (1980). The Value of Wealth: A Comment on Dworkin and Kronman. Journal of Legal Studies 9: 243-52.

POSNER, R. A. (2000). Cost-Benefit Analysis: Definition, Justification, and Comment on Conference Papers, The Journal of Legal Studies, Vol. 29, No. S2 (June 2000), pp. 1153-1177. DOI: $\underline{10.1086 / 468108}$

REISMAN, G. (2005). Platonic Competition. Accessed pm December 20 from https://mises.org/library/platonic-competition

RIZZO, M. J. (1979). Uncertainty, Subjectivity, and the Economic Analysis of Law, in RIZZO, M. J. (ed.), Time, Uncertainty, and Disequilibrium, Lexington, MA: Lexington Books, pp. 71-90

RIZZO, M. J. (1980). The Mirage of Efficiency, Hofstra Law Review, Vol. 8, pp. 641658.

ROTHBARD, M. N. (1956). Toward a Reconstruction of Utility and Welfare Economics. In SENNHOLZ, M. ed. On Freedom and Free Enterprise: The Economics of Free Enterprise, Princeton, N.J: D. Van Nostrand.

ROTHBARD, M. N. (1977). Do you hate the state? The Libertarian Forum, Vol. 10, No. 7, July; http://www.lewrockwell.com/rothbard/rothbard75.html

ROTHBARD, M. N. (1979). Comment: The Myth of Efficiency, in RIZZO, M. J. (ed.), Time, Uncertainty, and Disequilibrium, Lexington, MA: Lexington Books: pp. 91-96

ROTHBARD, M. N. (1982). Law, Property Rights, and Air Pollution, Cato Journal, Vol. 2, No. 1, Spring; reprinted in BLOCK, W. E., (ed.) Economics and the Environment: A Reconciliation, Vancouver: The Fraser Institute, 1990, pp. 233-279; http://mises.org/story/2120.

ROTHBARD, M. N. (1991). The End of Socialism and the Calculation Debate Revisited. The Review of Austrian Economics, Vol. 5, No. 2, pp. 51-76. Reprinted in The Logic of Action One: Method, Money, and the Austrian School. Glos, UK: Edward Elgar Publishing Ltd., 1997, pp. 408-437; DOI: 10.1007/BF02426928

ROTHBARD, M. N. (1992). The Present State of Austrian Economics. Working Paper from the Ludwig von Mises Institute, November. Reprinted in The Logic of Action One: Method, Money, and the Austrian School. Glos, UK: Edward Elgar Publishing Ltd., 1997, pp. 111-172. Reprinted in Journal des Economistes et des Etudes Humaines, Vol. 6, No. 1 (March 1995), pp. 43-89.

ROTHBARD, M. N. (1997a). Toward a Reconstruction of Utility and Welfare Economics, in The Logic of Action: Method, Money and the Austrian School, Vol. I, Cheltenham, UK: Edward Elgar, pp. 211-254; https://mises.org/store/EconomicControversies-P10459.aspx 
ROTHBARD, M. N. (1997b). Buchanan and Tullock's 'The Calculus of Consent, The Logic of Action II, UK: Edward Elgar Publishing Limited, pp. 269-274; http://library.mises.org/books/Murray\%20N\%20Rothbard/Economic\%20Controversies. pdf

ROTHBARD, M. N. (1997c). The Logic of Action: Applications and Criticism from the Austrian School, Vol. II, Cheltenham, UK: Edward Elgar

ROTHBARD, M. N. (2011). Buchanan and Tullock's 'The Calculus of Consent, Chapter 5;Economic Controversies. Auburn, AL: Mises Institute

RUSSELL, C.S. (2001). Applying Economics to the Environment. Oxford: Oxford University Press.

SALERNO, J. T. (1990a). Ludwig von Mises as Social Rationalist, Review of Austrian Economics, Vol. 4, pp. 26-54; http://www.mises.org/journals/rae/pdf/rae4_1_2.pdf

SALERNO, J. T. (1990b). Postscript: Why a Socialist Economy is Impossible, in MISES, L. von, Economic Calculation in the Socialist Commonwealth. Auburn AL: Praxeology Press, pp. 51-71

SALERNO, J. T. (1991). Commentary: The Concept of Coordination in Austrian Macroeconomics, in EBELING, R. E. (ed.), Austrian Economics, Perspectives on the Past and Prospects for the Future. Champions of Freedom Series. Vol. 17. Hillsdale, Mich.: Hillsdale College Press.

SALERNO, J. T. (1993). Mises and Hayek Dehomogenized, Review of Austrian Economics, Vol. 6, No. 2, pp. 113-146;DOI: $10.1007 / \mathrm{BF} 00842707$

SALERNO, J. T. (1994). Reply to Leland B. Yeager on 'Mises and Hayek on Calculation and Knowledge.' Review of Austrian Economics, Vol. 6, No. 2, pp. 113-146

SALERNO, J. T. (1995). A Final Word: Calculation, Knowledge and Appraisement, Review of Austrian Economics, Vol. 9, No. 1, pp. 141-142; DOI: 10.1007/BF01101887

SALERNO, J. T. (2011). Perfect Competition: "Gobble”-degook, Access on November 24 from http://blog.mises.org/19459/perfect-competition-gobble-degook/

SALIN, P. (1996). Cartels as Efficient Productive Structures. The Review of Austrian Economics. Vol. 9, No. 2, pp. 29-42; DOI: 10.1007/BF01103328

SAMUELSON P. (1954). The Pure Theory of Public Expenditure. Review of Economics and Statistics 36 (4): 387-389. DOI: 10.2307/1925895

SCHMIDTZ, D. (1991). The Limits of Government: An Essay on the Public Goods Argument, Boulder Co: Westview Press

Schrepel, Thibault. 2015. "'Perfect Competition' and Antitrust” May 6; https://mises.org/library/perfect-competition-and-antitrust

SECHREST, L. (2003). Privateering and National Defense: Naval Warfare for Private Profit, pages 239-74, in HOPPE, H. H. (ed.) The Myth of National Defense: Essays on the Theory and History of Security Production, published by the Ludwig von Mises Institute, Auburn, Alabama. 
SECHREST, L. (2004a). Public Goods and Private Solutions in Maritime History. The Quarterly Journal of Austrian Economics. Vol. 7, No. 2. Summer, 3-27. http://www.mises.org/journals/qjae/pdf/qjae7_2_1.pdf;

SECHREST, L (2004b). Private Provision of Public Goods: Theoretical Issues and Some Examples from Maritime History, ICFAI Journal of Public Finance, August, Vol. II, No. 3, 45- 73; http://www.mises.org/journals/scholar/Sechrest7.pdf

SECHREST, L. (2007). Privately Funded and Built U.S. Warships in the Quasi-War of 1797-1801, The Independent Review, Summer, Vol. 12, No. 1: 101-113.

SHUGART, W., MCCHESNEY, F. (1995). The Causes and Consequences of Antitrust: The Public-Choice Perspective . Chicago: University of Chicago Press. Stiglitz Joseph (2008), "Information" in Encyclopedia of Economics, Liberty Fund, Indianapolis.

SOBEL, R. S., LEESON. P. T. (2006). Government's response to Hurricane Katrina: A public choice analysis. Public Choice; April, Volume 127, Issue 1-2, pp. 55-73; https://link.springer.com/article/10.1007/s11127-006-7730-3

STALEBRINK, O. J. (2004). The Hayek and Mises Controversy: Bridging Differences. Quarterly Journal of Austrian Economics, Vol. 7, No. 1, Spring, pp. 27-38; DOI: 10.1007/s12113-004-1033-7

STIGLER, G. J., BECKER, G. S. (1977). De Gustibus Non Est Disputandum, American Economic Review, 67: 76-90.

STIGLITZ, J., WEISS, A. (1981). Credit Rationing in the Market with Imperfect Information, American Economic Review, vol. 71, pp. 393-410.

STRINGHAM, E. (2001). Kaldor-Hicks Efficiency and the Problem of Central Planning, The Quarterly Journal of Austrian Economics, Vol. 4. No. 2.

STRINGHAM, E. (ed.) (2005). Anarchy, State, and Public Choice. Cheltanham, UK: Edward Elgar.

STRINGHAM, E. (2008). Economic Value and Cost Are Subjective, in The Handbook of Austrian Economics, Peter Boettke (editor), Cheltenham, UK: Edward Elgar $\mathrm{Pu}-$ blishing; http://mises.org/journals/scholar/stringham4.pdf

SUTTER, D. (1995). Asymmetric power relations and cooperation in anarchy. Southern Economic Journal, 61, 602-613. DOI: 10.2307/1060984

TINSLEY, P. (1998-1999). With Liberty and Justice for All: A Case for Private Police, Journal of Libertarian Studies, Vol. 14, No. 1, Winter, pp. 95-100; http://www.mises.org/journals/jls/14_1/14_1_5.pdf

TOLLISON, R., MCKORMICK. R. (1981). Politicians, Legislation, and the Economy: An Inquiry into the Interest Group Theory of Government. Boston, MA: Martinus Nijhoff, 1981.

WENZEL, R. (2016a). Walter Block On the Intellectual War Path." Accessed on April 25 from https://www.economicpolicyjournal.com/2016/04/walter-block-on-intellectualwar-path.html 
WENZEL, R. (2016b). The Best Footnotes I Have Read This Week. Accessed on October 11 from http://www.economicpolicyjournal.com/2016/10/the-best-footnotes-i-haveread-this-week.html

WEST, E., MCKEE, M. (1983). De Gustibus Est Disputandum: The Phenomenon of "Merit Wants" Revisited, The American Economic Review, December, Vol. 73, No. 5., pp. 1110-1121.

WESTLEY, Ch. (2012). Joseph Stiglitz's Market-Failure Myth. Accessed on January 5 from https://mises.org/library/joseph-stiglitzs-market-failure-myth

WILLIAMSON, C. R. (2010). Exploring the failure of foreign aid: The role of incentives and information. The Review of Austrian Economics; March, Volume 23, Issue 1, pp. 17-33; https://link.springer.com/article/10.1007/s11138-009-0091-7

WOODS, T. E. Jr. (2009a). Meltdown: A Free-Market Look at Why the Stock Market Collapsed, the Economy Tanked, and Government Bailouts Will Make Things Worse. Washington D.C.: Regnery Publishing

WOODS, T. E. Jr. (2009b). Response to the 'Market Failure' Drones, Accessed on June 10 from http://mises.org/story/3503

WOODS, T. E. Jr. (2009c). Krugman Failure, Not Market Failure, Accessed on June 19 from http://www.lewrockwell.com/woods/woods116.html

ZHANGKAI, H., LIXING, L., GUANGRONG, M., XU, L. C., (2017). Hayek, Local Information, and Commanding Heights: Decentralizing State-Owned Enterprises in China. American Economic Review. Vol. 107, No. 8, August, pp. 2455-78; 